\title{
Penggunaan Material Cold Mix Asphalt untuk Penanganan Penambalan Lubang
}

\author{
Tisara Sita \\ Balai Besar Pelaksanaan Jalan Nasional Jawa Tengah-D. I. Yogyakarta \\ *e-mail: tisarasita@pu.go.id
}

\begin{abstract}
Abstrak
Jalan merupakan prasarana transportasi darat yang berperan sangat penting dalam mendukung distribusi barang dan jasa yang menunjang tingkat perekonomian suatu wilayah. Namun di sisi lain, aktivitas masyarakat yang tinggi berbanding lurus dengan volume serta frekuensi beban lalu lintas yang tinggi pula pada suatu ruas jalan yang berpeluang untuk mereduksi kualitas perkerasan jalan. Pothole merupakan salah satu kerusakan yang perlu mendapatkan penanganan khusus dikarenakan bentuknya yang terlihat sangat jelas dan dapat mengurangi kestabilan kendaraan. Preservasi jalan pada pothole atau lubang dapat dilakukan dengan material yang mudah dan efektif, yaitu stockpiled cold mix asphalt yang memiliki keunggulan berikut: efisien dari segi waktu, perkerasan dapat dilalui oleh kendaraan segera setelah aplikasi cold mix, serta pemeliharaan dapat dilakukan pada kondisi cuaca apapun. Teknik pelaksanaan patching dengan material cold mix asphalt dapat dilakukan dengan: throw-and-go; throw-and- roll; semi permanen; serta spray-injection. Pada pemeliharaan rutin, teknik throw-and- roll lebih direkomendasikan untuk digunakan. Modifikasi dapat dilakukan pada cold-mix asphalt untuk memodifikasi kekuatannya. Penambahan semen terbukti dapat menjadi bahan aditif dan admixture pada cold mix asphalt sehingga properti mekanik dalam cold mix asphalt berpotensi untuk termodifikasi menjadi ekivalen dan setara dari segi kekuatan dengan hot mix asphalt.
\end{abstract}

Kata kunci: cold-mix asphalt, patching, pothole

(1) \$ Licensees may copy, distribute, display and perform the work and make derivative works and remixes based on it only if they give the author or licensor the credits (attribution) in the manner specified by these. Licensees may copy, distribute, display, and perform the work and make derivative works and remixes based on it only for non-commercial purposes.

\section{PENDAHULUAN}

Jalan merupakan prasarana transportasi darat yang berperan sangat penting dalam mendukung distribusi barang dan jasa yang menunjang tingkat perekonomian suatu wilayah serta berbagai aspek kehidupan masyarakat lainnya. Merupakan suatu hal yang lazim jika aktivitas masyarakat, baik dalam kegiatan ekonomi maupun kegiatan lainnya, sangat dipengaruhi oleh kondisi jalan pada daerah tersebut.

Di sisi lain, aktivitas masyarakat yang tinggi berbanding lurus dengan volume serta frekuensi beban lalu lintas yang tinggi pula pada suatu ruas jalan yang berpeluang untuk mereduksi kualitas perkerasan jalan sehingga tidak optimal dalam melayani beban lalu lintas rencana. Kerusakan yang mungkin terjadi pada perkerasan jalan dapat diklasifikasikan menjadi (ASTM D6433, 2007): retak kulit buaya (alligator cracking); kelebihan aspal (bleeding); retak blok (block cracking); tonjolan dan lengkungan (bump and sags); keriting (corrugation); amblas (depressions); retak tepi (edge cracking); retak refleksi sambungan (joint reflection cracking); penurunan bahu jalan (lane/shoulder drop off); retak memanjang atau melintang (longitudinal or transversal cracking); tambalan dan galian utilitas (patching and utility cut patching); pengausan (polished aggregate); lubang (potholes); persilangan jalan rel (railroad crossing); alur (rutting); sungkur (shoving); retak selip (slippage cracking); pengembangan (swell); serta pelapukan dan pelepasan butir (weathering and raveling). 
Di antara kerusakan-kerusakan yang telah disebutkan, pothole merupakan salah satu kerusakan yang perlu mendapatkan penanganan khusus dikarenakan bentuknya yang terlihat sangat jelas (Gambar 1) dan dampak yang disebabkan oleh pothole itu sendiri. Pothole merupakan lubang dengan ukuran yang bervariasi, yang terkadang mencapai bagian binder base course pada perkerasan yang disebabkan oleh disintegrasi material pada lapisan perkerasan (Kar dan Jain, 2015). Karena berbentuk seperti cekungan, pothole dapat menyebabkan pengemudi kehilangan kendali terhadap kendaraannya, sehingga rawan mengakibatkan kecelakaan lalu lintas.

Kerusakan pothole pada umumnya disebabkan oleh kondisi perkerasan yang lembab; kondisi beku-leleh atau pasang-surut air yang berkelanjutan; kondisi lapisan dasar yang kurang menunjang; kondisi beban lalu lintas berlebih; atau kombinasi dari beberapa kondisi tersebut di atas.
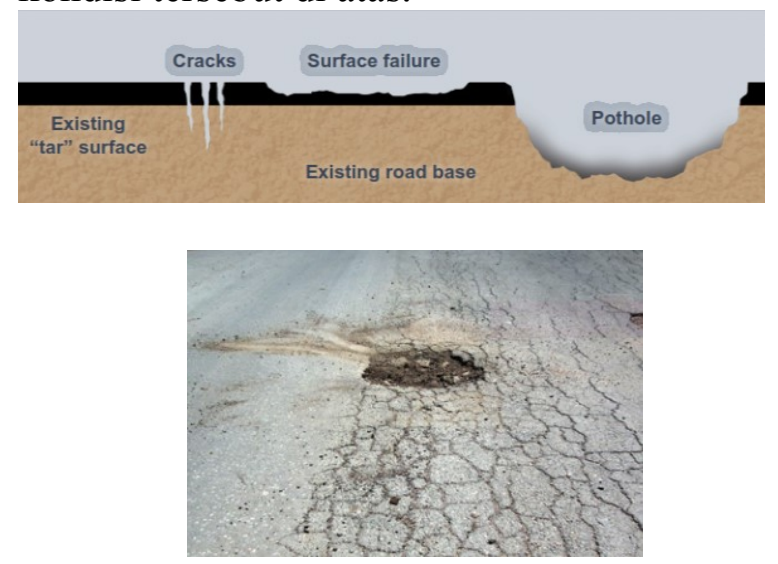

Gambar 1. Perbedaan Kerusakan Pothole dengan Kerusakan Perkerasan Lainnya dan Contoh Kerusakan Pothole

(Sumber: Pothole Repair Manual, National Cold Asphalt)

Sebagai negara tropis dengan curah hujan tahunan yang cukup tinggi, beberapa area di Indonesia merupakan area yang rawan terhadap banjir. Sepanjang tahun 2020, tercatat terdapat 409 peristiwa banjir di seluruh Indonesia (BNPB, 2020). Hal ini mengakibatkan ruas-ruas jalan di daerah tersebut rawan pula terhadap kerusakan pothole. Oleh karena itu, inovasi dalam penambalan pothole penting untuk dilakukan dan dikaji lebih lanjut.

\section{PENGGUNAAN COLD MIX SEBAGAI MATERIAL PRESERVASI POTHOLE}

Keputusan preservasi pothole dapat dipengaruhi oleh beberapa faktor, yaitu:

a. Arus lalu lintas;

b. Lama waktu hingga rehabilitasi atau rencana overlay;

c. Ketersedian personel, peralatan, dan material;

d. Toleransi masyarakat yang melintasi ruas tersebut.

Penambalan pada pothole dapat dilakukan sebagai pemeliharaan darurat pada kondisi cuaca yang ekstrim maupun sebagai pemeliharaan rutin pada kondisi cuaca yang memungkinkan dikarenakan penambalan dapat dilakukan pada suhu udara $-18^{\circ} \mathrm{C}$ hingga $38^{\circ} \mathrm{C}$. Walaupun dapat dilakukan pada berbagai macam kondisi cuaca, penambalan pothole dilakukan dengan menggunakan material yang serupa dan tidak jauh berbeda di Amerika Serikat maupun Kanada (Wilson dan Romine, Federal Highway Administration). Kualitas patching pothole dipengaruhi oleh pemilihan material serta prosedur patching itu sendiri.

Beberapa sumber menyatakan bahwa patching pothole sebaiknya dilakukan dengan warm mix asphalt. Namun, pengerjaan warm mix asphalt tidak jauh berbeda dengan hot mix asphalt yang membutuhkan plant tersendiri (NCHRP Sythesis 463). Material yang paling mudah dan efektif dalam penambalan pothole adalah stockpiled cold mix (Kandhal, 2008 dalam Kar dan Jain, 2015). Cold mix umumnya digunakan karena ketiadaan hot mix asphalt (HMA), namun belakangan ini cold mix menjadi material preservasi perkerasan (sebagai material patching sementara) yang umum ditemui. Dalam hal ini, cold mix, cold emulsion mix, atau generic stockpile mix merupakan suatu istilah yang merujuk pada suatu campuran aspal yang dapat disiapkan persediaannya dan dikerjakan di saat dingin; material ini diproduksi di plant hot mix asphalt, kemudian didinginkan sebagai persediaan untuk digunakan di kemudian hari (NCHRP Sythesis 463). Keuntungan cold mix sebagai material patching antara lain: 
a. Efisien dari segi waktu;

b. Perkerasan dapat dilalui oleh kendaraan segera setelah aplikasi cold mix;

c. Pemeliharaan dapat dilakukan pada kondisi cuaca apapun;

d. Sisa material tidak banyak;

e. Tenaga kerja yang diperlukan sedikit;

f. Ramah lingkungan dan mudah untuk diaplikasikan.

Kekurangan utama cold mix adalah biaya yang tinggi dalam aplikasinya. Selain itu, jika tidak diaplikasikan dan diaplikasikan dengan tepat, kerusakan pothole dapat berkembang menjadi kehilangan material melalui raveling, kurangnya adhesi, serta dishing (NMDOT, 2007).

Material cold mix dibagi menjadi 3 jenis, yaitu:

a. Cold mix yang diproduksi oleh plant lokal menggunakan agregat dan binder apapun yang tersedia, sehingga tidak terdapat kompatibilitas terhadap pothole eksisting;

b. Cold mix yang diproduksi sesuai dengan spesifikasi badan pelaksana pengguna cold mix tersebut. Spesifikasi yang disyaratkan meliputi tipe agregat dan aspal, serta beberapa kriteria sesuai dengan kualitas badan pelaksana;

c. Cold mix yang merupakan milik asphalt plant lokal. Plant memformulasikan cold mix dengan binder khusus. Binder ini pada umumnya merupakan milik suatu perusahaan yang ingin mengetes agregat lokal, mendesain campurannya dan memantau produksinya sehingga dapat menjamin kualitas produk cold mix tersebut.

\section{TEKNIK PRESERVASI UNTUK KERUSAKAN POTHOLE DENGAN MENGGUNAKAN COLD-MIX ASPHALT}

Beberapa teknik preservasi yang dapat dilakukan untuk melakukan patching dengan material cold-mix asphalt, yaitu:

a. Throw-and-Go

Metode ini merupakan metode yang paling umum digunakan untuk patching karena sangat cepat diaplikasikan, sehingga menekan biaya. Melalui metode ini, material patching dimasukkan ke dalam pothole yang tidak diperlakukan secara khusus (tidak diberikan treatment apapun sebelumnya). Lubang tersebut mungkin saja mengandung air atau sisa-sisa material. Sementara, pemadatan dilakukan dengan lalu lintas setelah dilakukan patching, atau dipadatkan secara sederhana dengan menggunakan sekop secara manual.

\section{b. Throw-and-Roll}

Alternatif ini lebih unggul dibandingkan teknik sebelumnya. Dalam teknik ini, material dimasukkan ke dalam pothole yang belum ditreatment dan dipadatkan menggunakan alat pemadat. Dengan menggunakan metode ini patching menjadi lebih padat dan meningkatkan usia tambalan tersebut. Pemadatan tambalan biasanya berlangsung selama 1-2 menit. Dalam jangka panjang, pothole hanya perlu ditambal dengan frekuensi lebih jarang, sehingga meningkatkan produktivitas dan penghematan biaya bagi pelaksana.

c. Semi-Permanen

Prosedur ini seringkali dianggap prosedur terbaik dibandingkan rehabilitasi secara keseluruhan. Dalam metode ini, pertama-tama pothole dibersihkan dari air dan puing-puing. Sisi-sisi lubang pun dibentuk dikeruk dengan bentuk persegi hingga suatu kedalaman perkerasan yang dianggap aman. Selanjutnya, material ditempatkan di area pothole dan dipadatkan dengan peralatan seperti vibratory plate compactors atau singledrum vibratory rollers. Dengan teknik ini, tambalan tersebut menjadi sangat padat sehingga usia tambalan menjadi lebih panjang. Kelemahan dari metode ini adalah biaya tenaga kerja dan peralatan yang cukup signifikan, serta produktivitas yang lebih rendah dibandingkan dengan dua metode sebelumnya (Wilson dan Romine 1994).

\section{d. Spray-Injection}

Teknik ini paling efektif dalam melakukan preservasi kerusakan retak transversal dan pothole. Pothole dibersihkan dari air dan residu disemprotkan lapisan pelapis pada sisi dan bagian bawah lubang. Berikutnya, campuran disemprotkan ke dalam lubang sebelum ditutup dengan lapisan agregat. Teknik ini tidak memerlukan 
pemadatan sehingga dapat meningkatkan produktivitas walaupun meningkatkan biaya peralatan.

Menurut evaluasi lapangan di berbagai negara bagian di Amerika serikat (Wilson dan Romine 1994), terdapat beberapa temuan terkait teknik pelaksanaan patching dengan material cold mix, yaitu:

1. Performa tambalan yang dilakukan dengan metode throw-and-roll dapat dibandingkan dengan tambalan semipermanen, hal ini dibuktikan dengan tiga campuran material yang berbeda.

2. Teknik throw-and-roll lebih efisien dari segi biaya dibandingkan dengan teknik semi-permanen dikarenakan produktivitas yang lebih tinggi dengan biaya yang lebih rendah. Oleh karena itu, untuk pemeliharaan rutin, teknik throwand-roll lebih disarankan.

3. Namun, perlu dicatat bahwa kesuksesn teknik throw-and-roll juga bergantung pada penggunaan material yang berkualitas baik.

4. Spray-injection merupakan metode yang cukup layak. Namun, teknik ini sangat bergantung pada keahlian operator. Selain itu, bentuk agregat juga perlu disesuaikan dengan emulsi aspal yang digunakan.

5. Teknik yang paling tepat untuk digunakan di musim dingin adalah throw-and-roll atau spray-injection dikarenakan waktu pengerjaannya yang cepat.

\section{INOVASI DAN MODIFIKASI COLD MIX ASPHALT DAN METODE APLIKASI COLD MIX ASPHALT}

\section{Modifikasi Material Cold-Mix Asphalt}

Berbagai penelitian telah dilakukan untuk meningkatkan kekuatan cold mix asphalt. Penambahan material pada cold mix asphalt dapat mengubah properti materialnya. Penambahan semen terbukti dapat menjadi bahan aditif dan admixture pada cold mix asphalt yang menggunakan emulsi bitumen yang bertindak sebagai binder (Fang, 2016). Campuran tersebut dikenal dengan Cement Bitumen Emulsion Asphalt (CBEA).
Penambahan semen mengakibatkan properti mekanik dalam cold mix asphalt berpotensi untuk termodifikasi menjadi ekivalen dan setara dari segi kekuatan dengan hot mix asphalt. Penambahan Ordinary Portland Cement (OPC) juga dapat meningkatkan modulus kekakuan serta modulus resilien dari cold-mix asphalt. Semakin tinggi level OPC yang ditambahkan ke dalam cold-mix asphalt, akan semakin meningkatkan modulus kekakuan serta modulus resilien suatu campuran cold-mix asphalt (Choudary, dkk, 2012, Gambar 2).

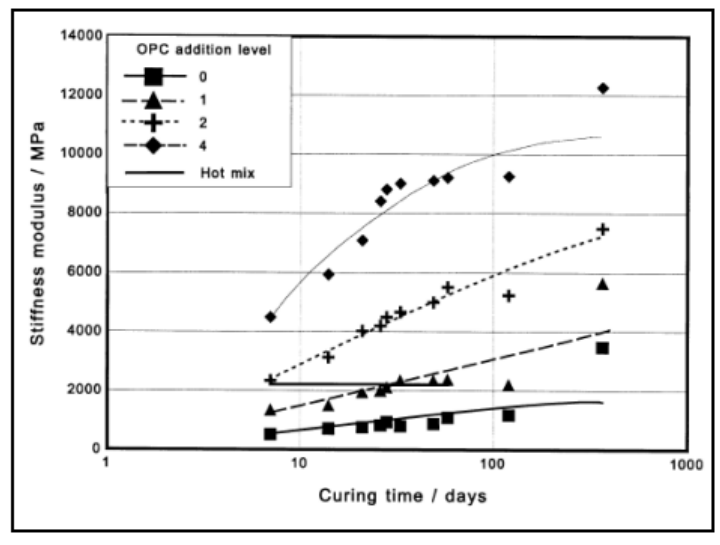

Sumber: Brown dan Needham dalam Choudary, 2012 (a)

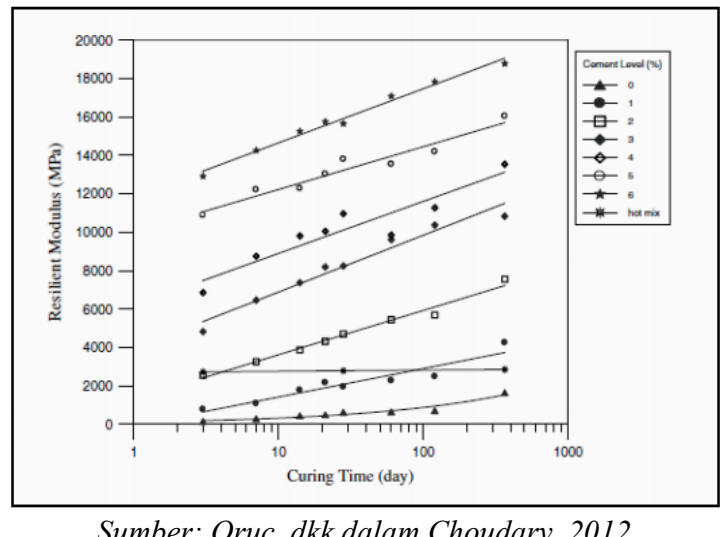

(b)

Gambar 2. (a) Efek Penambahan OPC terhadap Modulus Kekakuan Cold Mix Asphalt; (b) Efek Penambahan Semen terhadap Resilient Modulus Cold Mix Asphalt

Cold mix asphalt yang dimodifikasi dengan material semen memiliki tingkat homogenitas yang rendah, serta dibutuhkan waktu curing yang lebih lama hingga mencapai kekuatan optimumnya. Selain itu, hasil penelitian menunjukkan bahwa terdapat rongga udara dengan jumlah yang signifikan diakibatkan oleh penguapan air. Hal ini 
berpotensi memicu kerusakan akibat kelembaban.

Performa cationic quick set emulsified asphalt juga dapat ditingkatkan dengan menambahkan emulsi polyvinyl acetat (PVACE). Penambahan PVAC-E dinilai dapat meningkatkan kekuatan tekan dari material campuran, sehingga memiliki resistensi yang lebih tinggi terhadap kerusakan rutting dan fatigue yang diakibatkan oleh beban lalu lintas yang tinggi. Sifat termoplastik sintetik adhesive dari PVAC-E membuat daya lekat antara agregat dengan aspal meningkat, sehingga meningkatkan kekuatan tekan hingga $31 \%$ dibandingkan dengan CMA yang tidak dimodifikasi (Chaves-Valencia, dkk, 2006). Campuran PVAC-CMA direkomendasikan digunakan dalam keadaan kering, yaitu dengan menyediakan waktu curing yang cukup. Hal ini dikarenakan PVAC- CMA dalam keadaan basah memiliki kekuatan tekan 20\% lebih rendah dibandingkan PVAC-CMA dalam keadaan kering.

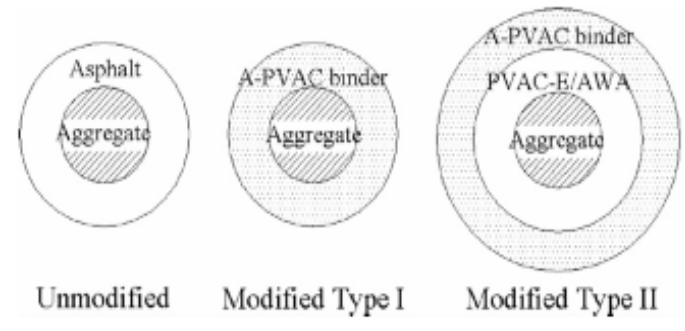

Gambar 3. Dua Jenis Modifikasi ColdMix Asphalt dengan PVAC-E

\section{Perkembangan Metode Pelaksanaan Cold Mix Asphalt}

Selain

$$
\text { modifikasi }
$$

material, perkembangan metode pelaksanaan patching dengan cold mix asphalt juga perlu ditindaklanjuti. Hal ini dilakukan agar pelaksanaan menjadi lebih efektif dari sisi waktu dan biaya tanpa perlu melibatkan modifikasi material yang probabilitas pelaksanaannya cenderung rendah.

Saat ini, mesin yang digunakan merupakan mesin impor yang kurang efisien dari sisi biaya (Gambar 4). Selain itu, ukuran mesin yang besar menyebabkannya sulit untuk menjangkau daerah-daerah dengan akses jalan yang sempit. Kesulitan pemeliharaan pothole di daerah-daerah tersebut dikhawatirkan dapat meningkatkan biaya rehabilitasi perkerasan di kemudian hari akibat penundaan preservasi pothole. Oleh karena itu, CSIR - Central Road Research Institute India membuat suatu inovasi baru dengan merakit suatu mesin yang berukuran handy dan lebih tahan lama dibandingkan mesin yang tersedia di pasar India. Mesin tersebut menggunakan sistem pneumatic compressor dan terdiri dari dua buah kotak (masing-masing untuk agregat kasar dan agregat halus) serta dua buah tangki (masing-masing untuk aspal emulsi dan air). Selain itu, terdapat suatu mixer yang dapat beroperasi sesuai dengan mix design yang diinput oleh operator.

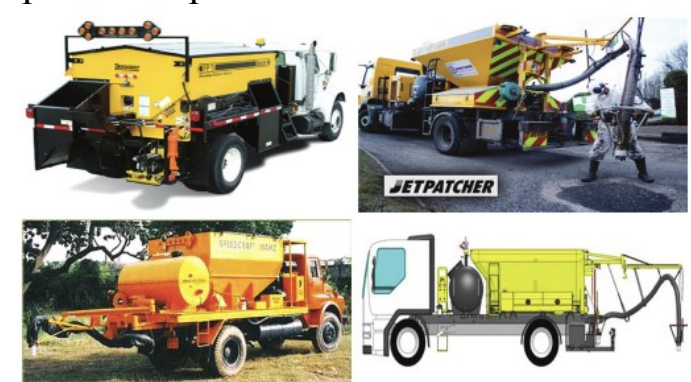

(a)

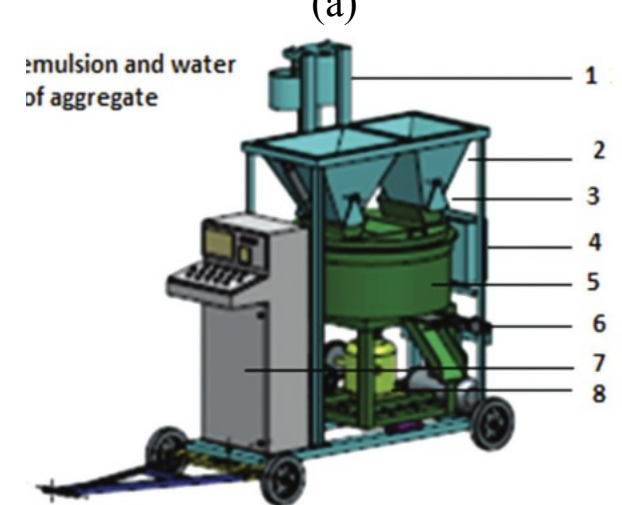

Keterangan:

1. Tangki untuk penyimpanan aspal emulsi dan air

2. Hoppers untuk penyimpanan agregat kasar dan halus

3. Sistem penimbangan berat

4. Kompresor udara

5. Mixing unit

6. Sprayer

7. Panel kontrol

8. Pompa

Gambar 4. (a) Mesin Impor Untuk Pelaksanaan Preservasi dengan Cold Mix Asphalt; (b) Mesin Modifikasi oleh CSIR - Central Road Research Institute India

Mesin tersebut memiliki kompresor udara untuk memberihkan pothole. Kemudian, pothole diisi dengan material cold mix yang dicampur sesuai dengan mix design oleh prosesor. Pemadatan dilakukan menggunakan mesin yang sama, sehingga perkerasan dapat 


\section{Tisara Sita}

Penggunaan Material Cold Mix Asphalt untuk Penanganan Penambalan Lubang

dilalui oleh lalu lintas sekitar 20-30 menit setelah pemadatan.

Cold-mix asphalt juga dapat digunakan sebagai material utama dalam konstruksi jalan di daerah-daerah terpencil, yaitu sebagai green paving mix. Beberapa hal yang perlu diperhatikan dalam produksi cold-mix asphalt untuk keperluan konstruksi jalan baru yaitu: perlunya penambahan zad aditif agar properti mekanik cold-mix asphalt setara dengan hotmix asphalt; serta waktu curing yang perlu diperhatikan (Choudary, dkk., 2012).

\section{KESIMPULAN}

Preservasi jalan pada pothole atau lubang dapat dilakukan dengan material yang mudah dan efektif, yaitu stockpiled cold mix asphalt yang memiliki keunggulan berikut: efisien dari segi waktu, perkerasan dapat dilalui oleh kendaraan segera setelah aplikasi cold mix, serta pemeliharaan dapat dilakukan pada kondisi cuaca apapun. Teknik pelaksanaan patching dengan material cold mix asphalt dapat dilakukan dengan: throw-andgo; throw-and- roll; semi permanen; serta spray-injection. Pada pemeliharaan rutin, teknik throw-and-roll lebih direkomendasikan untuk digunakan. Penambahan semen terbukti dapat menjadi bahan aditif dan admixture pada cold mix asphalt sehingga properti mekanik dalam cold mix asphalt berpotensi untuk termodifikasi menjadi ekivalen dan setara dari segi kekuatan dengan hot mix asphalt.

\section{DAFTAR PUSTAKA}

Chavez-V alencia, L.E., dkk. (2006). "Improving The Compressive Strengths Of Cold-Mix Asphalt Using Asphalt Emulsion Modified By Polyvinyl Acetate." Construction and Building Materials, 21 (2007), pp.583- 589.

Choudary, R., dkk. (2012). "Use of Cold Mixes for Rural Road Construction." International Journal of Computer Applications.

Fang, X. (2016). A Fundamental Research On Cold Mix Asphalt Modified With Cementitious Materials.

Kar, Siksha S., dan Jain, Dr P K. (2015). An Innovative Method for Repair of Potholes, India.

New Mexico Transportation. Department of (2007). Pavement Maintenance Manual, Santa Fe, New Mexico.

Sainz, M. (2016). Pothole Patching: A Review on Materials and Methods. Peoria: Bradley University.

Wilson, T.P., dan Romine, A.R. (1994). Materials and Procedures for Repair of Potholes in Asphalt Surfaced Pavements: Manual of Practice Strategic Highway Research Program National Research. Virginia.https://bnpb.go.id/infografis/inf ografis-data-bencana-tgl-18-april-2020 